К.С. Васюта, О.Л. Кащишин, О.П. Ковальчук, О.С. Тютюнник

Харківський національний університет Повітряних Сил ім. І. Кожедуба, Харків

\title{
МЕТОД ВИЯВЛЕННЯ РАДІОЛОКАЦІЙНОГО СКЛАДЕНОГО ХАОТИЧНОГО СИГНАЛУ ПРИ НАКОПИЧЕННІ СУРОГАТНИХ ДАНИХ
}

\begin{abstract}
Форма складених хаотичних радіолокаційних сигналів дуже сильно спотворюється в реальних умовах поширення радіохвиль при їх відбитті від рухомих складних повітряних суден та від місиевих об'єктів, щзо знаходяться в районі аеродрому та районі заходу на посадку літальних апаратів. Якість обробки таких сигналів, в такому випадку, значно погіршується. В роботі показано, щяо можливо застосовувати зондуючий сигнал невеликої потужності в радіолокаційних системах посадки, щзо в свою чергу дозволяє забезпечити більш високу скритність їх роботи, але наявність флуктуацій параметрів такого сигналу, значно знижує якість такої обробки. Для підвищення якості обробки таких сигналів при малих відносинах сигнал-цум необхідно враховувати їх специфічну структуру. Пропонується застосування технологї формування сурогатних сигналів, щзо дозволить істотно підвищити якість виявлення складеного хаотичного радіолокаџійного сигналу з параметрами, що відхиляються. Для збереження спектральних, кореляційних та нелінійних властивостей сигналів, щуо приймаються, рекомендовано новий алгоритм формування сурогатних сигналів. У разі застосування сурогатних сигналів, при обробиі складених хаотичних сигналів, з являється можливість підвищити вірогідність їх правильного виявлення на 15 - 25\%.
\end{abstract}

Ключові слова: кореляційна обробка, складений хаотичний сигнал, флуктуація, дисперсія, повітряне судно, сурогатний сигнал, якість виявлення.

\section{Вступ}

Останнім часом для прихованої роботи радіолокаційних систем посадки (РСП) перспективним $є$ застосовування складних шумоподібних сигналів, до яких відносяться складені хаотичні сигнали. Застосування традиційних (кореляційних) методів обробки таких сигналів [1-2] не забезпечує показників якості виявлення, які висуваються до роботи РСП. Для обробки складених хаотичних сигналів необхідно використовувати некласичні методи обробки, як показано в роботі [3-4], які враховують їх специфічні властивості через динамічні інваріанти.

Форма складених хаотичних сигналів сильно спотворюється в реальних умовах поширення радіохвиль. Під час відбиття таких сигналів від повітряних суден спостерігаються схожі викривлення. Але якість їх обробки при цьому значно погіршується [2]. Тому, для вирішення цього питання, необхідно компенсувати флуктуації амплітуди та фази складеного хаотичного сигналу, що виникають. Реалізувати компенсацію флуктуацій можливо за рахунок використання технології формування сурогатних сигналів, яка дає можливість отримати велику кількість клонів сигналу, що приймається, при цьому зберігаючи його властивості. На основі отриманих клонів можливе усереднення випадкових флуктуацій параметрів складених хаотичних сигналів.

Поняття “сурогатні дані" було введено Theiler [5] в 1992 році використовувалося в контексті стати- стичного тестування тимчасового ряду на нелінійність. Але на теперішній час вже мається велика кількість методів формування сурогатних даних, наприклад, бутстреп-процедури [6], які дозволяють зберігати лінійні властивості процесу.

Відомі наступні алгоритми формування сурогату:

- алгоритм формування сурогатів тимчасової зміни (temporal shift surrogate - TSS), які застосовуються для перевірки наявності нелінійних залежностей в сигналі;

- алгоритми формування сурогатних даних шляхом невеликої перестановки (small-shuffle surrogate - SSS), які слугують для перевірки не стаціонарності часового ряду, та інші [7].

Необхідно підкреслити, що при застосуванні даних способів не можливо зберегти лінійні або нелінійні властивості складних процесів одночасно.

Використовувати алгоритм формування сурогатів траєкторії аттрактора (attractor trajectory surrogate ATS) [8] при виявленні хаотичних сигналів запропоновано в роботі [3], що використовується для емпіричної оцінки відношення правдоподібності. Алгоритм ATS дозволяє формувати сурогатні сигнали, що зберігають нелінійні властивості складених хаотичних сигналів, тобто їх траєкторії в псевдофазовому просторі, а також їхні спектральні та кореляційні властивості. Тому доцільно застосовувати алгоритм ATS, який дозволить підвищити якість виявлення складеного хаотичного сигналу при кореляційній обробці. 
Аналіз останніх досліджень і публікацій. Вимоги, що висуваються до радіолокаційних систем (РЛС) постійно зростають. В середині 60 -х років $\mathrm{XX}$ сторіччя 3'явилися способи підвищення роздільної здатності РЛС по дальності, шляхом застосування в якості зондувального сигналу ЛЧМ та ФКМ радіоімпульсів. Таким чином одночасно досягались і велика енергія випромінення, яка властива довгому зондуючому імпульсу та висока роздільна здатність по дальності, яка властива короткому стислому сигналу за рахунок узгодженої обробки.

На теперішній час на озброєнні військ інформаційних систем та радіотехнічного забезпечення польотів авіації знаходяться такі радіолокаційні системи посадки (РСП), як РСП-6М2, РСП-10, РСП10МА [9], в яких застосовуються довгі ЛЧМ та ФКМ радіоімпульси (тривалістю близько десятків мікросекунд). Це стало можливим за рахунок застосування нової елементної бази, зокрема твердотільних транзисторних передавачів і цифрової приймальної апаратури.

До РСП, висуваються більш жорсткі вимоги. По перше, необхідно якомога більше інформації витягти з радіолокаційного обсягу, а по-друге необхідно отримати якомога більш тонкий інструмент для його аналізу, забезпечуючи при цьому високу роздільну здатність та перешкодозахищеність (скритність роботи) системи.

Виходячи 3 цього, в останні роки активно проектуються та розробляються радіолокаційні системи (РЛС), що працюють в режимі підвищеної скритності (Low Probability of Intercept radar) [10]. Це досягається забезпеченням їх роботи під “шум”.

Одним з варіантів вирішення вказаних проблем - $є$ застосування складених хаотичних сигналів. Кореляційні властивості складених хаотичних сигналів [1], кореляційний метод обробки складеного хаотичного сигналу [4] метод генерування складеного хаотичного сигналу радіолокаційних систем [11], дозволяють використовувати його в якості зондуючого сигналу при побудові РСП, оскільки вони володіють високою роздільною здатністю по дальності, а збільшення довжини імпульсу дозволить забезпечити високу роздільну здатність по частоті та необхідну енергію випромінювання.

Метою статті $\epsilon$ вирішення задачі виявлення складеного хаотичного сигналу на фоні білого шуму при його спотворенні за рахунок поширення в неоднорідній тропосфері та перевідбитті від рухомих складних повітряних суден та від місцевих об'єктів, що знаходяться в районі аеродрому та районі заходу на посадку літальних апаратів, а також синтез пристрою виявлення радіолокаційного складеного хаотичного сигналу 3 параметрами, що флуктуюють, застосовуючи технологію формування сурогатних сигналів.

\section{Виклад основного матеріалу}

Відомо, що турбулентність тропосфери призводить до флуктуацій іiї показника заломлення, яка в свою чергу викликає флуктуації параметрів сигналу [12].

Експериментальні та теоретичні дані, що викладені в [13-14] показують, що в утворенні фазових флуктуацій радіосигналів найбільший внесок здійснюють турбулентності тропосфери 3 зовнішнім масштабом від сотень метрів до одиниць кілометрів.

При поширенні сигналу в неоднорідному середовищі можлива його модуляція за випадковим законом. В роботі [15] показано, що флуктуації фази та амплітуди радіосигналів розподілені по нормальному закону. 3 урахуванням залежності від довжини хвилі, флуктуації фази в тропосфері істотні для сантиметрових і більш коротких хвиль, а флуктуації амплітуди - для субміліметрових та більш коротких хвиль [13]. Тому в подальшому флуктуаціями амплітуди можна знехтувати.

Для фазових флуктуацій [15-16], що поширені по нормальному закону, при гаусовій формі коефіцієнта кореляції флуктуації показника заломлення тропосфери, вираз дисперсії фазових флуктуацій має вигляд

$$
\sigma_{\phi}^{2}=\frac{\sqrt{\pi}}{2} \sigma_{n}^{2} k^{2} S L_{0},
$$

де $\sigma_{n}^{2}$ - дисперсія флуктуацій показника заломлення тропосфери;

$$
\begin{aligned}
& k=\frac{2 \pi}{\lambda}-\text { хвильове число; } \\
& \lambda-\text { довжина хвилі радіосигналу; } \\
& S-\text { шлях пройдений хвилею в тропосфері; } \\
& L_{0}-\text { середній розмір турбулентної неоднорід- }
\end{aligned}
$$
ності.

В [16] розраховані величини дисперсії фазових флуктуацій радіосигналу, який пройшов вільну тропосферу із середнім розміром турбулентної неоднорідності $L_{0} \approx 100$ м. Значення дисперсії флуктуацій показника заломлення лежить в межах $\sigma_{n}{ }^{2}=0,25 \cdot 10^{-12}-0,25 \cdot 10^{-10}$, причому, перша цифра відповідає середнім умовам, а друга є максимально можливою. Результати розрахунку виражені в pad $^{2}$ і зібрані в табл. 1.

Таблиця 1

Значення дисперсій фазових флуктуацій $\sigma_{\phi}^{2}$ при поширенні електромагнітної хвилі в тропосфері

\begin{tabular}{|c|c|c|}
\hline$L_{0}, M$ & \multicolumn{2}{|c|}{100} \\
\hline$S=50, c M$ & 3 & 10 \\
\hline & \multicolumn{2}{|c|}{$\sigma_{n}{ }^{2}=0,25 \cdot 10^{-12}$} \\
\hline
\end{tabular}




\begin{tabular}{|c|c|c|}
\hline \multicolumn{2}{|c|}{ Закінчення табл. 1 } \\
\hline \multirow{2}{*}{$S=50 \kappa м$} & $0,48 \cdot 10^{-1}$ & $0,44 \cdot 10^{-2}$ \\
& $0,97 \cdot 10^{-1}$ & $0,87 \cdot 10^{-2}$ \\
$S=200 \kappa м$ & $1,94 \cdot 10^{-1}$ & $1,74 \cdot 10^{-2}$ \\
\hline & $\sigma_{n}{ }^{2}=0,25 \cdot 10^{-10}$ \\
\hline$S=50 \kappa м$ & 4,8 & 0,44 \\
$S=100 \kappa м$ & 9,7 & 0,87 \\
$S=200 \kappa м$ & 19,4 & 1,74 \\
\hline
\end{tabular}

Джерело:[14, С. 217].

Таке повітряне судно, як літак, має складну форму, внаслідок чого сумарний відбитий сигнал $\epsilon$ векторною сумою групи відбитих сигналів від окремих частин повітряного судна (літального апарату), наприклад від двигунів, гвинтів, фюзеляжу та площин. Рух повітряного судна та його частин відносно РСП викликає зміни сумарного відбитого сигналу по часу, що призводить до флуктуацій сигналу при радіолокаційному вимірі координат і параметрів руху повітряного судна. Дані флуктуації, викликані тільки самим повітряним судном, без врахування впливу атмосфери і шуму РСП, називаються шумом повітряного судна [15].

Нехай повітряне судно опромінюється складеним хаотичним сигналом $X(t)$ сформованим за допомогою поліному Чебишева першого роду третього порядку рис. 1.

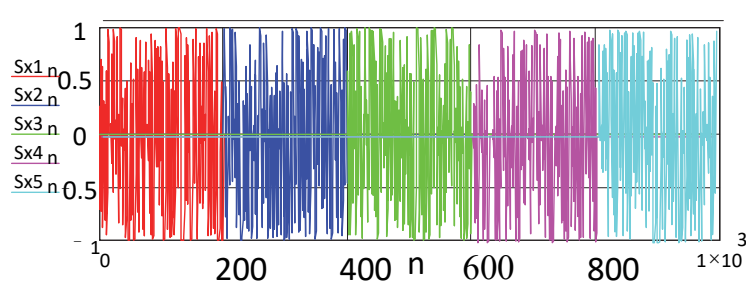

Рис. 1. Складений хаотичний радіоімпульс Джерело: розроблено авторами.

$X(t)=X(t) 1+X(t) 2+X(t) 3+X(t) 4+X(t) 5, \quad$ де $X(t) 1, X(t) 2, X(t) 3, X(t) 4, X(t) 5$ - складові складеного хаотичного сигналу з різними початковими даними;

$X(t)$ - складений хаотичний сигнал.

Кореляційні властивості складеного хаотичного сигналу розглянуто попередніх публікаціях $[1 ; 4$; $11]$.

Тоді відбитий від реального повітряного судна сигнал буде випадковим образом промодульований по амплітуді і фазі

$$
y(t)=B(t) \dot{X}(t) e^{j 2 \pi\left(F_{\partial c p} t+\beta(t)\right)},
$$

де $B(t)$ та $\beta(t)$ - закони зміни випадкових компонент амплітуди і фази відбитого сигналу, обумовлені амплітудними та фазовими шумами повітряного судна;

$$
\begin{aligned}
& X(t) \text { - сигнал, що очікуємо; } \\
& F_{Д с p} \text { - середня частота Допплера, що обумов- }
\end{aligned}
$$
лена рухом центру відбиття з радіальною швидкістю $V_{r c p}$.

Експериментальні дослідження показують, що щільність ймовірності амплітудного множника $B(t)$ в (2) істотним чином залежить від типу повітряного судна. Розподіл амплітуд відбитого сигналу для широкого класу повітряних суден часто апроксимують $m$ - розподілом (розподілом Накагамі) $m=1,2,3, \ldots$ [8].

$$
p(B, m)=\left(\frac{2 m^{m} B^{2 m-1}}{\Gamma(m)}\right) e^{\left(-m B^{2}\right)}, B \geq 0,
$$

де $\frac{2 m^{m}}{\Gamma(m)}-$ нормуючий коефіцієнт;

$\Gamma(m)$ - гамма-функція.

Закон розподілення випадкової фази $\beta$ відбитого сигналу (2) майже для всіх випадків, що зустрічаються на практиці [16] - є рівномірним.

$$
p(\beta)=\frac{1}{2 \pi}, 0 \leq \beta \leq 2 \pi .
$$

Вид розподілу Накагамі ілюструється на рис. 2. для $m=1, m=2, m=5$.

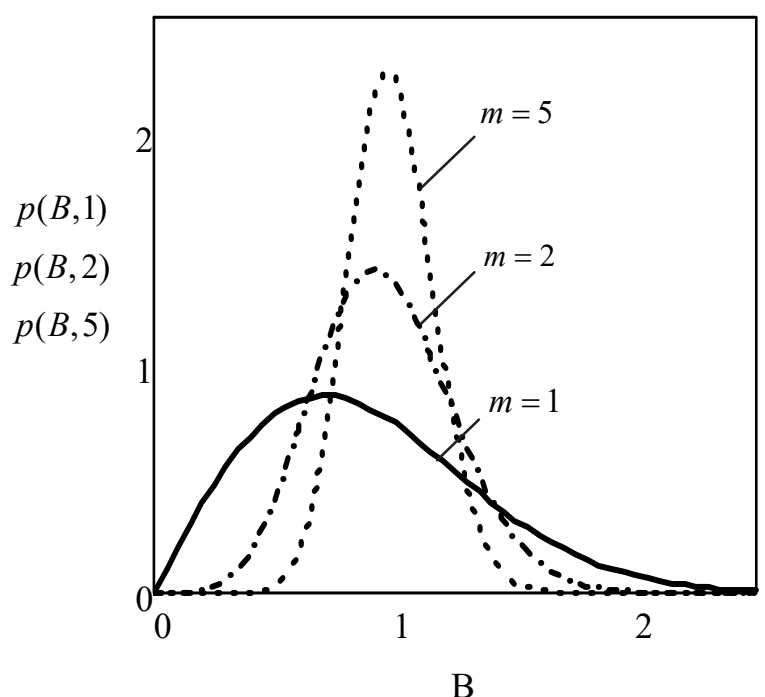

Рис. 2. Розподіл амплітуд відбитого сигналу Джерело: розроблено авторами.

3 аналізу рис. 2. видно, що при $m=1$ розподіл (3) переходить до розподілу Релея 


$$
p(B)=2 B e^{\left(-B^{2}\right)} .
$$

Така модель гарно описує флуктуації сигналу, відбитого від повітряного судна, що має велике число блискучих точок приблизно однакової інтенсивності. Цей випадок характерний для опису флуктуацій відбитого сигналу бомбардувальника або винищувача 3 великою кількістю елементів на зовнішніх підвісках, що опромінюються електромагнітною хвилею сантиметрового діапазону.

Для даного випадку статистичного опису повітряного судна відповідає нормальний закон розподілу амплітуд $b_{c}, b_{s}$ множника $B=\sqrt{b_{c}^{2}+b_{s}^{2}}$.

$$
p\left(b_{c, s}\right)=\frac{1}{\sqrt{\pi}} e^{\left(-b_{c, s}^{2}\right)} .
$$

Якщо серед блискучих точок повітряного судна виділяється домінуючий відбивач, то використовують розподіл (3) з параметрами $m=2$ або $m=3$. При $m \rightarrow \infty$ розподіл (3) описують поведінку не флюктуючого повітряного судна [16].

При проведенні чисельного моделювання кореляційної обробки складеного хаотичного сигналу сигнал, що очікується $X(t)$ представлявся дискретною величиною та задавався в комплексному вигляді:

$$
X_{t}=X c_{t}+i X s_{t},
$$

де $X c_{t}=x c_{t}, \quad x c_{t+1}=\left(4 x c_{t}\right)^{3}-3 x c_{t} \quad 3$ початковою умовою поліному $\quad x c_{0}=0.162, \quad$ a $\quad X s_{t}=x s_{t}$, $x s_{t+1}=\left(4 x s_{t}\right)^{3}-3 x s_{t}$ з початковою умовою поліному $x s_{0}=0.365$.

Виходячи з вище описаного, модель відбитого від повітряного судна сигналу, з урахуванням поширення в неоднорідній тропосфері буде мати вигляд:

$$
y_{t}=B_{t} \dot{X}_{t} e^{j 2 \pi\left(F_{\partial c p} t+\beta_{t}\right)} e^{j \phi_{t}},
$$

де $\varphi_{t}-$ випадкова величина зміни фази при поширенні сигналу в тропосфері підпорядкована нормальному розподілу.

Тоді реалізація, що приймається $Y_{t} \epsilon$ адитивною сумішшю білого шуму $\xi_{t}$ і відбитого сигналу $y_{t}$.

$$
Y_{t}=y_{t}+\xi_{t} .
$$

Спираючись на вище викладений матеріал, математичне моделювання виявлення складеного хаотичного сигналу, з урахуванням фазових та амплітудних флуктуацій при проходженні тропосфери та відбитті від повітряного судна на фоні білого шуму, проводилось методом багатоканальної кореляційної обробки [4; 17].

Моделювання проведено для наступних випад- ків:

1. При відсутності флуктуацій параметрів сигналу за рахунок перевідбиття від повітряного судна та проходження тропосфери;

2. При наявності слабо флуктуіруючого повітряного судна та слабких флуктуаціях фази сигналу, за рахунок поширення в тропосфері. В цьому випадку закон зміни множника $B_{t}$ апроксимований (3) 3 $m=5$, а значення дисперсії флуктуації фази величини $\varphi_{t}$ приймались $\sigma_{\phi}^{2}=0,45 \cdot 10^{-2}$;

3. При наявності середньо флуктуіруючого повітряного судна та середніх флуктуаціях фази сигналу за рахунок поширення в тропосфері. В цьому випадку закон зміни множника $B_{t}$ апроксимований (3) $3 m=2$, а значення дисперсії флуктуації фази величини $\varphi_{t}$ приймались $\sigma_{\phi}^{2}=0,89 \cdot 10^{-2}$;

4. При сильно флуктуіруючому повітряному судні та сильних флуктуаціях фази сигналу за рахунок поширення в тропосфері. В цьому випадку закон зміни множника $B_{t}$ апроксимований (3) 3 $m=1$, а значення дисперсії флуктуації фази величини $\varphi_{t}$ приймались $\sigma_{\phi}^{2}=1,78 \cdot 10^{-2}$.

На рис. 3 ілюструються фазові портрети моделі складеного хаотичного радіоімпульсу, що випромінений $x_{t}$ та відбитого $y_{t}$ складеного хаотичного радіоімпульсу.
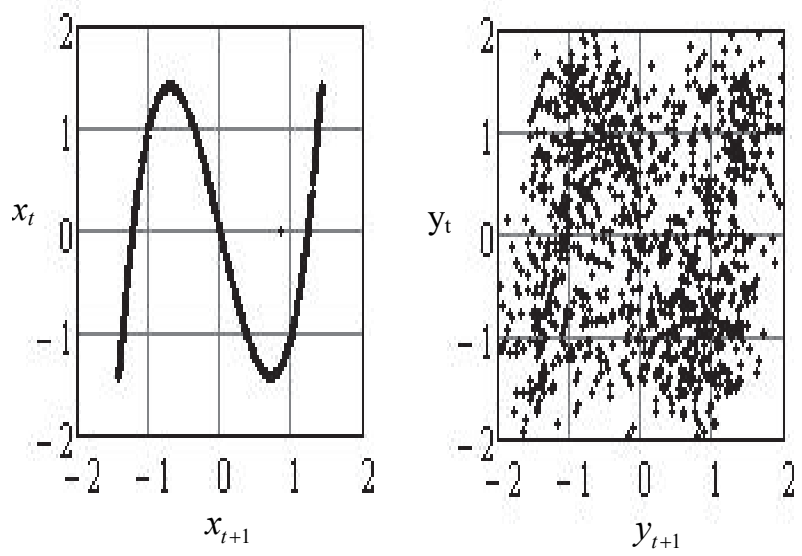

Рис. 3. Фазові портрети випромінюваного $x_{t}$ та відбитого $y_{t}$ складеного хаотичного радіоімпульсу Джерело: розроблено авторами.

3 аналізу рис. 3 видно, що перевідбиття істотно спотворює форму сигналу і його фазовий портрет. Це викликає необхідність застосування методів нелінійного аналізу при обробці таких сигналів.

На рис. 4 приведені результати чисельного розрахунку залежностей вірогідності правильного виявлення D (D1, D2, D3, D4 для випадків 1, 2, 3, 4 відповідно) від відношення сигнал-шум $q$ при зада- 
ній вірогідності помилкової тривоги $F=10^{-6}$.

Для моделювання кожного випадку формувалось 100 спостережуваних реалізацій, що складались 31100 значень та, що містять по 5 повітряних суден, що виявляються. Крива 1 отримана для ідеалізованих умов та є орієнтиром для оцінки впливу трансформації складеного хаотичного сигналу на показники якості його виявлення при кореляційній обробці.

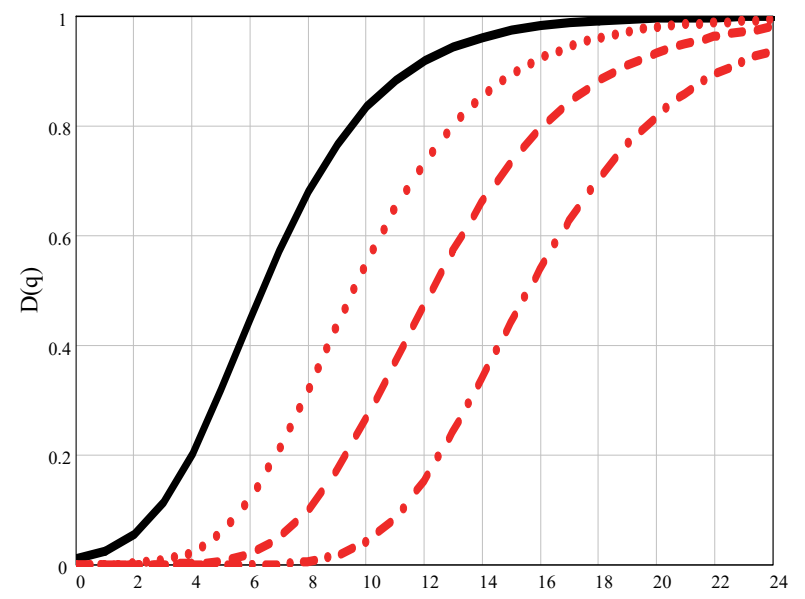

q

Рис. 4. Криві виявлення складеного хаотичного сигналу при кореляційній обробці Джерело: розроблено авторами.

Аналіз рис. 4. показує, що при кореляційній обробці складеного хаотичного радіоімпульсу без урахування флуктуацій його параметрів, вірогідність правильного виявлення $D=0.9$ досягається при відношенні сигнал-шум менше 1 , тобто $M$, за рахунок високого стиснення.

Це говорить про можливість застосування зондуючого сигналу невеликої потужності, що в свою чергу дозволяє забезпечити більш високу скритність роботи РСП. Але наявність флуктуацій амплітуди та фази відбитого складеного хаотичного сигналу приводить до зниження вірогідності його правильного виявлення, наприклад, для сильних флуктуацій $D=0.9$ забезпечується при $q=22 d B$.

Розглянемо випадок виявлення радіолокаційного складеного хаотичного сигналу на фоні білого гаусового шуму у випадку нормальних флуктуацій параметрів сигналу.

Допустимо, що реалізація на приймачі:

$$
y_{t}=x_{t}+\xi_{t},
$$

$\epsilon$ адитивною сумішшю корисного складеного хаотичного сигналу $x_{t}$, що сформовано за допомогою поліному Чебишева першого роду третього порядку та білого шуму $\xi_{t}$.

3 прийнятої реалізації, 3 метою компенсації флуктуації фази та амплітуди сигналу, при їхньому нормальному законі розподілення, отримаємо безліч сурогатів, з якими в подальшому проведемо статистичне усереднення.

Скористаємось алгоритмом ATS, що представлено в роботі [8] та отримаємо сурогатний сигнал 3 (9). Нижче показано наступний порядок розрахунку:

1. Визначимо векторний часовий ряд $\left\{z_{t}\right\}_{t=1}^{N-d_{w}}$ з елементами $z_{t}=\left(y_{t}, y_{t+\tau}, y_{t+2 \tau}, \ldots, y_{t+d_{e} \tau}\right)$ вкладенням скалярного часового ряду $\left\{y_{t}\right\}_{t=1}^{N}$ в псевдофазовий простір 3 часовою затримкою $\tau$. Для спрощення виберемо вікно вкладки $d_{w}=d_{e} \tau-1$, де $d_{e}$ - розмірність вкладки;

2. Виберемо початковий стан $s_{1} \in\left\{z_{t} \mid t=1, \ldots, N-d_{w}\right\}$;

3. Припустимо $i=1$;

4. Навмання виберемо для $s_{i}$ одного сусіднього з більшості $\left\{z_{t} \mid t=1, \ldots, N-d_{w}\right\}$, наприклад, $z_{j}$;

5. Введемо $s_{i+1}=z_{j+1}$ та збільшимо $i$;

6. Повторимо цю процедуру від пункту 4 , доки $i=N$;

7. візьмемо $\left\{\left(s_{t}\right)_{1}: t=1,2, \ldots, N\right\}$, як сурогатний часовий ряд, в якому $(\cdot)_{1}$ позначає скалярну першу координату вектору.

Для отримання ансамблю з $M$ сурогатних сигналів $s_{t}^{M}$ необхідно повторити вище приведений алгоритм $M$ разів. Компенсація флуктуацій реалізується шляхом статистичного усереднення ансамблю з $M$ сурогатних сигналів.

Проведене моделювання показало, що алгоритм ATS дозволяє отримати з великою швидкістю формування безлічі сурогатних сигналів $s_{t}^{m}$ та при цьому зберігати всі властивості вихідного спостереження.

При цьому статистичне усереднення приводить до компенсації шуму спостереження. На рис. 5 представлено фазові портрети реалізації $y_{t}$ та отриманого сурогатного сигналу:

$$
s s_{t}=\frac{\sum_{m=1}^{M} s_{t}^{m}}{M},
$$

де $M$ - кількість сурогатних сигналів.

Фазовий портрет прийнятої реалізації більше зашумлений, як видно 3 рис. 5, а усереднений сурогат має вигляд більше структурованого.

Таким чином при застосуванні сурогатних сигналів можливо значно компенсувати шум спостереження.

Звідси випливає, що можна очікувати, що така компенсація шуму спостереження в прийнятій реа- 
лізації дозволить знизити поріг виявлення складеного хаотичного сигналу і як висновок підвищити якість його виявлення.



Рис. 5. Фазові портрети: прийнятої реалізації $y_{t}$ та усередненого сурогатного сигналу $s s_{t}$

Джерело: розроблено авторами.

Розглянемо в подальшому більш складний випадок, коли будемо вести спостереження складеного хаотичного сигналу у випадку флуктуацій його параметрів, які викликані його поширенням в неоднорідній тропосфері та відбиттям від складних наземних об'єктів.

Таким чином вираз буде виглядати наступним чином:

$$
y_{t}=b_{t} x_{t} e^{j 2 \pi\left(F_{\partial c p} t+\beta_{t}\right)} e^{j \phi_{t}}+\xi_{t},
$$

де $b_{t}$ та $\beta_{t}$ - випадкові компоненти амплітуди та фази відбитого сигналу, які обумовлені амплітудними та фазовими шумами повітряного судна;

$x_{t}$ - сигнал, що очікується;

$F_{\partial c p}$ - середня частота Допплера;

$\phi_{t}$ - випадкова величина зміни фази з нормальним розподілом [2; 18].

Після проведення чисельного моделювання, бачимо, що усереднення сурогатного сигналу, з спостереження (11), приводить до часткової компенсації не тільки шуму, але і флуктуації амплітуди та фази відбитого сигналу при їх нормальному розподілі. Можливо застосовувати традиційну кореляційну обробку для виявлення корисного сигналу з усередненого сурогатного сигналу $[4 ; 17 ; 18]$.

На рис. 6 представлена синтезована схема пристрою виявлення з застосуванням сурогатних сигналів де:

ФСС - пристрій формування сурогатних сигналів; КШ та $\Phi$ - пристрій компенсації шуму та флуктуації; КСОС - кореляційна схема обробки сигналів; ПП - пороговий пристрій.

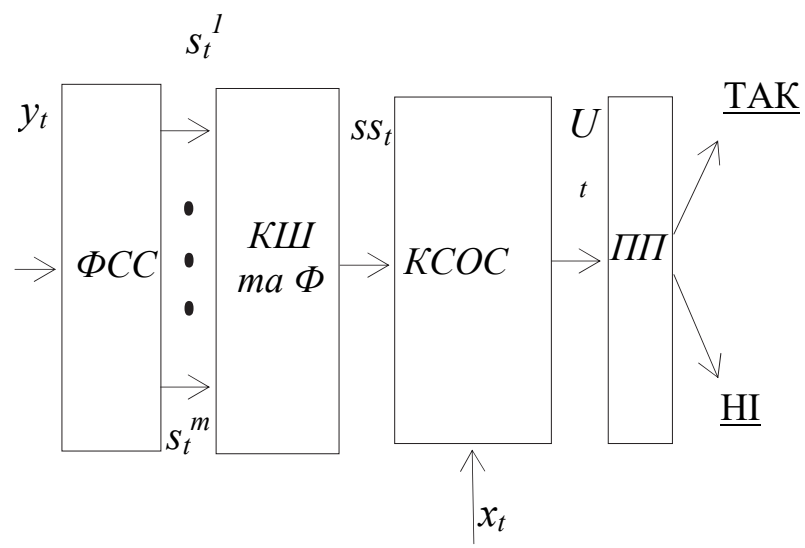

Рис. 6. Функціональна схема пристрою виявлення при застосуванні сурогатних сигналів Джерело: розроблено авторами.

На пристрій формування сурогатних сигналів (ФСС) надходить прийнята реалізація $y_{t}$, який здійснює алгоритм ATS для формування більшості сурогатів $s_{t}^{m}$. Сигнали, що сформовані, в подальшому, подаються в пристрій компенсації шуму та флуктуацій (КШ та Ф) за допомогою усереднення сукупності сурогатів. Отримана усереднена реалізація $s s_{t}$, в подальшому надходить до кореляційної схеми обробки сигналів (КСОС), де накопичується корисний сигнал. Рішення про наявність сигналу приймається в пороговому пристрої (ПП). Залежність напруги $U_{t}$ на виході кореляційної СОС показана на рис. 7 для випадків: відсутність флуктуацій $(A)$, наявність флуктуацій, без їх компенсації за допомогою сурогатних сигналів $(B)$; при компенсації флуктуацій за допомогою пристрою КШ та Ф шляхом усереднення сформованих сурогатів в пристрої ФСС (C). При проведенні аналізу залежностей (рис. 7) бачимо, що при застосуванні синтезованого алгоритму підвищується відношення сигнал-шум на виході інтегратору кореляційної СОС, тобто якість обробки такого сигналу підвищується.

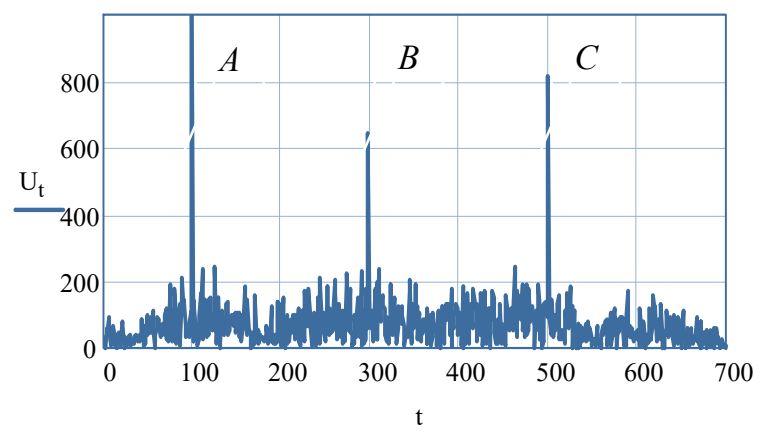

Рис. 7. Напруга на виході кореляційної СОС для випадків: А - при відсутності флуктуацій;

В - при наявності флуктуацій (без застосування сурогатів); С - при наявності флуктуацій

(з застосуванням сурогатів)

Джерело: розроблено авторами. 
При слабких флуктуаціях та великих відношеннях сигнал-шум достатньо сформувати до 100 сурогатних сигналів. При проведенні моделювання компенсації флуктуацій формувалось 1000 сурогатних реалізацій, як і в роботі [2]. Разом з цим, при проведенні чисельного моделювання виявлено, що для компенсації флуктуацій при зменшенні відношення сигнал-шум та збільшенні інтенсивності флуктуацій від слабких до більш сильних необхідно збільшувати кількість сурогатних сигналів до 1000. При подальшому збільшенні сурогатних сигналів особливого підвищення якості обробки сигналу не показує, при цьому час обробки збільшується. На рис. 8 показано криві виявлення, які оцінюють збільшення якості виявлення складеного хаотичного сигналу при застосуванні отриманої схеми виявлення (рис. 6). Криві лінії $D(q)$, що отримані при фіксованій вірогідності помилкової тривоги $F=10^{-6}$ без застосування алгоритму формування сурогатних сигналів (червоний колір), з застосуванням алгоритму формування сурогатних сигналів (синій колір), та 3 урахуванням застосування кореляційної обробки без урахування флуктуацій [2; 4; 17] (чорний колір), та розраховані для наступних випадків:

- без наявності флуктуацій (-);

- при врахуванні слабких флуктуацій (·);

- при врахуванні середніх флуктуацій (- -);

- при врахуванні сильних флуктуацій (- ·).



Рис. 8. Криві виявлення складеного хаотичного сигналу $\left(\mathrm{F}=10^{-6}\right)$ :

1) без урахування флуктуацій параметрів сигналу;

2) при слабких флуктуаціях; 3) при середніх флуктуаціях; 4) при сильних флуктуаціях.

Джерело: розроблено авторами.
При проведенні моделювання кожного випадку було сформовано сукупність 31000 сурогатних реалізацій (11), які складаються 31100 відліків та які містять по 3 корисних сигнали.

Після проведеного порівняння кривих ліній бачимо, що при застосуванні алгоритму формування сурогатних сигналів ATS, для підвищення якості виявлення знижується поріг виявлення:

- у разі сильних флуктуаціях параметрів сигналу - на 1,5 дБ;

- у разі середніх флуктуацій параметрів сигналу - на 2 дБ;

- у разі слабких флуктуацій параметрів сигналу - на 3 дБ;

Це відбувається внаслідок того, що у разі сильних флуктуацій параметрів сигналу закон зміни амплітуд сигналу видозмінюються від нормального закону розподілення вірогідностей до розподілу Релея та якість статистичного усереднення знижується.

\section{Висновки}

Таким чином, дослідження показали, що флуктуації амплітуди та фази складеного хаотичного радіолокаційного сигналу за рахунок поширення в неоднорідній тропосфері та відбитті від складних повітряних суден та від місцевих об'єктів, що знаходяться в районі аеродрому та районі заходу на посадку літальних апаратів, приводять до погіршення показників якості його виявлення при кореляційній обробці. Для підвищення якості обробки таких сигналів при малих співвідношеннях сигнал/шум необхідно враховувати їх специфічну структуру через динамічні властивості.

Тому, при застосуванні алгоритму формування сурогатних сигналів складеного хаотичного сигналу, для виявлення складеного хаотичного сигналу, що відбито від складних повітряних суден та від місцевих об'єктів, що знаходяться в районі аеродрому та районі заходу на посадку літальних апаратів, можна забезпечити компенсацію флуктуацій параметрів такого сигналу, які мають нормальний розподіл.

Запропоновано метод виявлення радіолокаційного зондуючого сигналу, який дозволяє підвищити вірогідність правильного виявлення складеного хаотичного сигналу при фіксованому значенні відношення сигнал-шум та вірогідності помилкової тривоги на $15-25 \%$.

\section{Список літератури}

1. Vasyuta K.S. Correlation Properties of a Composite Chaotic Radio Pulse / K.S. Vasyuta, O.L. Kashchyshyn // IEEE Ukrainian Microwaive Week. - Kharkiv, 22-27 June 2020. - P. 1022-1025. https://doi.org/10.1109 /UkrMW49653.2020.9252597. 
2. Васюта К.С. Анализ влияния флюктуаций параметров хаотического сигнала на качество его корреляционной обработки в измерительных радиотехнических системах / К.С. Васюта, Ф.Ф. Зоц, С.В. Озеров // Системи обробки інформації. - 2012. - № 7(105). - С. 60-63.

3. Новый подход к непараметрическому обнаружению хаотических сигналов на фоне белого шума с использованием "нелинейной динамической статистики” / П.Ю. Костенко, К.С. Васюта, А.Н. Барсуков та ін. // Збірник наукових праць Харківського університету Повітряних Сил. - 2010. - № 3(25). - С. 108-116.

4. Кореляційний метод обробки складеного хаотичного сигналу / К.С. Васюта, О.Л. Кащишин, О.П. Ковальчук, О.С. Тютюнник // Наука і техніка Повітряних Сил Збройних Сил України. - 2021. - № 1(42). - C. 100-106. https://doi.org/ 10.30748/nitps.2020.40.11.

5. Testing for nonlinearity in time series: The method of surrogate data / J. Theiler, S. Eubank, A. Longtin, B. Galdrikian, J.D. Farmer // Physica D. - 1992. - № 58. - P. 77-94.

6. Kantz H. Nonlinear time series analysis / H. Kantz, T. Schreiber. - Cambridge: United Kingdom University Press, 2004. $-369 \mathrm{p}$.

7. Small M. Applied Nonlinear Time Series Analysis Applications in Physics, Physiology and Finance / M. Small. - Singapore: World Scientific Publishing Co. Pte. Ltd., 2005. - P. 245.

8. Small M. Attractor trajectory surrogates: hypothesis testing and prediction / M. Small // International Symposium on Nonlinear Theory and its Applications. - Fukuoka, Japan, 29 November-3 December 2004. - P. 123-126.

9. Сучасний стан та перспективи розвитку радіолокаційних систем посадки / О.Л. Кащишин, К.С. Васюта, О.А. Ківшар, М.П. Долина // Наука і техніка Повітряних Сил Збройних Сил України. - 2019. - № 1(34). - С. 39-45. https://doi.org/10.30748/nitps.2019.34.05.

10. Pace P.E. Detecting and Classifying Low Probability of Intercept Radar / P.E. Pace. - London: Artech house, 2009. $862 \mathrm{p}$.

11. Васюта К.С. Метод генерування складеного хаотичного сигналу радіолокаційних систем / К.С. Васюта, О.Л. Кащишин // Наука і техніка Повітряних Сил Збройних Сил України. - 2020. - № 3(40). - С. $100-106$. https://doi.org/10.30748/nitps.2020.40.00.

12. Чернов Л.А. Распространение волн в среде со случайными неоднородностями / Л.А. Чернов. - М.: Наука, 1975. $-171 \mathrm{c}$

13. Радиоэлектронные системы: основы построения и теория. Справочник / С.А. Горшков, Д.И. Леховицкий, Н.Н. Минервин и др. / под. общ. ред. Я.Д. Ширмана. - М.: ЗАО “МАКВИС”, 1998. - 828 с.

14. Шифрин Я.С. Вопросы статистической теории антенн / Я.С. Шифрин. - М.: Сов. радио, 1970. -384 с.

15. Сколник М. Справочник по радиолокации / М. Сколник. - Т. 1. - М.: Сов. радио, 1976. - 456 с.

16. Локационная системотехника / В.Б. Алмазов, Г.С. Богословский, П.А. Брандис и др.; под общ. ред. В.Б. Алмазова. - Х.: ВИРТА, 1993. $-620 \mathrm{c}$.

17. Васюта К.С. Корреляционная обработка хаотических сигналов / К.С. Васюта, А.А. Грызо, Ф.Ф. Зоц // Збірник наукових праць Харківського університету Повітряних Сил. - 2012. - № 2(31). - С. 62-64.

18. Радиоэлектронные системы: основы построения и теория / Я.Д. Ширман, А.С. Маляренко, С.П. Лещенко и др. - М.: Радиотехника, 2007. - 512 с.

19. Макаров С.А. Оцінка стійкості системи зв'язку та радіотехнічного забезпечення / С.А. Макаров, С.П. Бєляк, О.В. Висоцький // Системи озброєння і військова техніка. - 2020. - № 1(61). - С. 44-50. https://doi.org/10.30748/ soivt.2020.61.05.

20. Застосування глобальних систем визначення місцеположення для підвищення бойових можливостей зенітних ракетних військ / С.П. Ярош, М.С. Буданов, О.Ю. Гапонов, Ю.О. Флячок // Збірник наукових праць Харківського національного університету Повітряних Сил. - 2019. - № 2(60). - С. 33-42. https://doi.org/10.30748/zhups.2019.60.05.

21. Новітні технології та засоби зв'язку у Збройних Силах України: шлях трансформації та перспективи розвитку / О.О. Лаврут, Т.В. Лаврут, О.К. Климович, Ю.М. Здоренко // Наука і техніка Повітряних Сил Збройних Сил України. 2019. - № 1(34). - C. 91-101. https://doi.org/10.30748/nitps.2019.34.13.

\section{Відомості про авторів:}

\section{Васюта Костянтин Станіславович} доктор технічних наук професор заступник начальника університету з навчальної роботи Харківського національного університету

Повітряних Сил ім. І. Кожедуба,

Харків, Україна

https://orcid.org/0000-0002-1978-3717

\section{Information about the authors:}

\author{
Konstantyn Vasiuta \\ Doctor of Technical Sciences Professor \\ Deputy Chief of Ivan Kozhedub \\ Kharkiv National \\ Air Force University to Academic Work, \\ Kharkiv, Ukraine \\ https://orcid.org/0000-0002-1978-3717
}


Кащишин Олександр Леонтійович

ад'юнкт

Харківського національного університету

Повітряних Сил ім. І. Кожедуба,

Харків, Україна

https://orcid.org/0000-0003-4447-9415

\section{Ковальчук Олександр Петрович}

заступник начальника факультету

Харківського національного університету

Повітряних Сил ім. І. Кожедуба,

Харків, Україна

https://orcid.org/ 0000-0003-1860-1720

Тютюнник Олександр Станіславович старший викладач кафедри

Харківського національного університету

Повітряних Сил ім. І. Кожедуба,

Харків, Україна

https://orcid.org/0000-0003-1435-7062
Oleksandr Kashchyshyn

Doctoral Student

of Ivan Kozhedub Kharkiv

National Air Force University,

Kharkiv, Ukraine

https://orcid.org/0000-0003-4447-9415

Oleksandr Kovalchuk

Deputy Head of the Faculty

of Ivan Kozhedub Kharkiv

National Air Force University,

Kharkiv, Ukraine

https://orcid.org/0000-0003-1860-1720

Oleksandr Tiutiunnyk

Senior Instructor

of Ivan Kozhedub Kharkiv

National Air Force University,

Kharkiv, Ukraine

https://orcid.org/0000-0003-1435-7062

\title{
МЕТОД ОБНАРУЖЕНИЯ РАДИОЛОКАЦИОННОГО СОСТАВНОГО ХАОТИЧЕСКОГО СИГНАЛА ПРИ НАКОПЛЕНИИ СУРРОГАТНЫХ ДАННЫХ
}

\author{
К.С. Васюта, А.Л. Кащишин, О.П. Ковальчук, А.С. Тютюнник
}

Форма составных хаотических радиолокационных сигналов очень сильно искажается в реальных условиях распространения радиоволн при их отражении от движущихся сложных воздушных судов и от местных объектов, находящчихся в районе аэродрома и районе захода на посадку летательных аппаратов. Качество обработки таких сигналов, в таком случае, значительно ухудшается. В работе показано, что возможно применять зондируюший сигнал небольиой мощности в радиолокаџионных системах посадки, в свою очередь позволяет обеспечить более высокую скрытность их работы, но наличие флуктуаций параметров такого сигнала, значительно снижает качество такой обработки. Для повышения качества обработки таких сигналов при малых отношениях сигнал-шум необходимо учитывать их специфическую структуру. Предлагается применение технологии формирования суррогатных сигналов, что позволит сушественно повысить качество обнаружения, составного хаотического радиолокационного сигнала с отклоняющимися параметрами. Для сохранения спектральных, коррелячионных и нелинейных свойств принимаемых сигналов, рекомендуется новый алгоритм формирования суррогатных сигналов. При использовании суррогатных сигналов, при обработке составных хаотических сигналов, появляется возможность повысить вероятность их правильного обнаружения на 15 $-25 \%$.

Ключевые слова: корреляционная обработка, составной хаотический сигнал, флуктуация, дисперсия, воздушное судно, суррогатный сигнал, качество обнаружения.

\section{METHOD FOR DETECTION OF RADAR COMPOSED CHAOTIC SIGNAL DURING SURROUND DATA ACCUMULATION}

\author{
K. Vasyuta, O. Kashchyshyn, O. Kovalchuk, O. Tiutiunnyk
}

The shape of the composite chaotic radar signals is very much distorted in real conditions of radio wave propagation when they are reflected from moving complex aircraft and from local objects located in the area of the aerodrome and the area of approach to the landing of aircraft. The processing quality of such signals, in this case, significantly deteriorates. The paper analyzes the possibility of traditional correlation (coherent) processing in detecting a complex chaotic radar signal against the background of white noise and its distortions during propagation in an inhomogeneous troposphere and reflection from a set of moving shiny points. It is shown that it is possible to use a low-power probing signal in radar landing systems, which in turn allows for higher secrecy of radar landing systems, but the presence of fluctuations in the parameters of such a signal reduces the quality of such processing. To improve the processing quality of such signals at low signal-to-noise ratios, it is necessary to take into account their specific structure due to the dynamic properties. It is also proposed to use the technology of forming surrogate signals, which will significantly improve the detection quality of the composite chaotic radar signal with deviating parameters. To preserve the spectral, correlation and nonlinear properties of the received signals, a new algorithm for generating surrogate signals is recommended. In the case of surrogate signals, when processing complex chaotic signals, it is possible to increase the probability of their correct detection by $15-25 \%$

Keywords: correlation processing, transformation of a composite chaotic signal, detection curves, fluctuation, variance, aircraft, surrogate signal, detection quality. 